\title{
FAILURE OF INHIBITION OF CHOLESTEROL BIOSYNTHESIS TO RETARD ATHEROMA*
}

\author{
BY \\ ANTHONY D. JOSE AND HOWARD J. PEAK \\ From the Hallstrom Institute of Cardiology, Royal Prince Alfred Hospital, Sydney, Australia
}

Received August 20, 1962

Triparanol (MER-29) $\dagger$ was the first known inhibitor of cholesterol biosynthesis to be used in man for the control of hypercholesterolæmia. Its specific action lowers the serum and tissue concentrations of cholesterol, but causes an almost equal accumulation of the closely related substance, desmosterol (Steinberg, Avigan, and Feigelson, 1961). Although MER-29 has recently been withdrawn because of its toxic effects, information about its influence on the development of atheroma in man is important with regard to future therapeutic approaches to this disease.

For the past eighteen months we have given MER-29 to a group of patients with very high serum cholesterol levels, in whom occlusive arterial disease predictably occurs early and advances rapidly. It was hoped that study of these patients with accelerated atheroma would show relatively quickly whether the activity of MER-29 would influence the development of atheroma. In a previous report (Jose, Learoyd, and Peak, 1961), the methods and initial results of this study have been described in detail. In two of the patients under treatment, evidence has been obtained, that strongly suggests that the administration of MER-29 does not influence the abnormal deposition of sterols in arteries or skin in hypercholesterolæmia.

\section{METHODS}

The methods for measurement of the serum sterols, phospholipids, and triglycerides are described elsewhere (Jose et al., 1961). Cholesterol and desmosterol concentrations were measured by combined use of the ferric chloride and Liebermann-Burchard colour reactions. Lipids were extracted from tissues by reflux distillation of homogenized tissue in ether for 24 hours. The ether was evaporated, and the lipids analysed by the methods used for serum.

\section{CASE RePorts}

Case 1. A youth, aged 18, suffered from essential hypercholesterolæmia and died from occlusive coronary artery disease in February 1962. He had first developed xanthomata on the hands at the age of 2 years. At the age of 8 , the serum cholesterol was $908 \mathrm{mg} . / 100 \mathrm{ml}$.

His condition was first reviewed by us in October 1960. He had no symptoms. Both parents were well and had serum cholesterols in the normal range: no evidence of a familial background was found. The only abnormalities on examination were multiple soft flat xanthomata on the arms, legs, and buttocks. An electrocardiogram was normal at rest and after strenuous effort. The serum cholesterol varied around $600 \mathrm{mg}$. $/ 100 \mathrm{ml}$. (Fig. 1). A typical analysis of the fasting serum lipids showed: cholesterol $610 \mathrm{mg} . / 100 \mathrm{ml}$. $(78 \%$ esterified), phospholipids $472 \mathrm{mg} . / 100 \mathrm{ml}$, and triglycerides $94 \mathrm{mg} . / 100 \mathrm{ml}$. He was started on MER-29 $500 \mathrm{mg}$. daily in December 1960, and this was continued for 14 months until his death. The changes in serum cholesterol, desmosterol, and total sterols during this time are shown in Fig. 1. In January 1961, one month after starting MER-29, he first developed chest discomfort related to exertion. By June 1961,

* Supported by Grant-in-Aid G-30 from the National Heart Foundation of Australia.

$\dagger$ Wm. S. Merrell Company. 


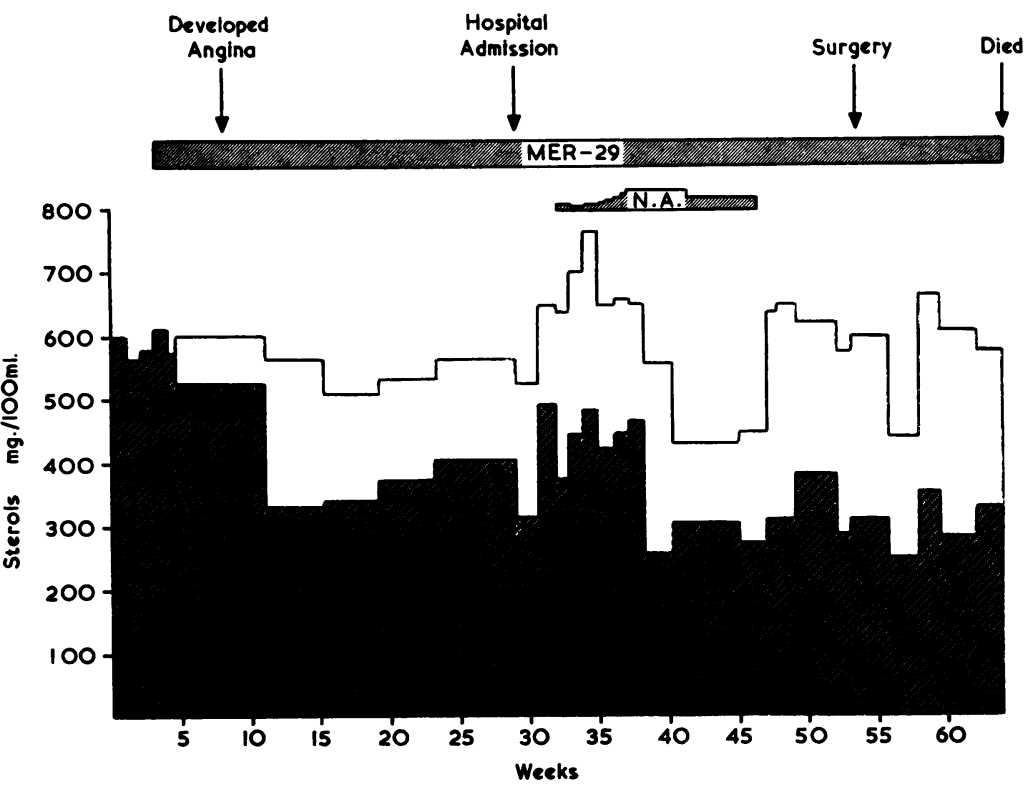

FIG. 1.-Serum sterol levels over the period of treatment in Case 1. The cholesterol level is indicated by the shaded area; in the presence of MER-29, the total sterol level is shown by the upper line (i.e. cholesterol plus desmosterol). N.A. = nicotinic acid treatment.

this had become much worse, and the cardiogram showed widespread ST-T wave changes of ischæmia. Hospital admission, bed-rest, anticoagulant treatment, and the addition of nicotinic acid in doses increasing to $6 \mathrm{~g}$. a day did not significantly affect his condition. Nicotinic acid was suspended after nine weeks when liver function tests became grossly abnormal. Anginal pain became progressively worse. In December 1961 a modified Beck operation was performed, but without appreciable benefit. The cardiogram continued to show fluctuating ST-T wave abnormalities without evidence of major infarction. He died at home eight weeks later, apparently in an attack of acute pulmonary odema.

At autopsy, large plaques and confluent areas of lipid deposition were found in the intima of the major arteries, especially concentrated at the base of the aorta and in the aortic arch. One large plaque totally occluded the orifice of the left coronary artery, and another encroached on the right coronary orifice. These arteries distal to their origins showed only slight atheroma. No thrombosis was found. The heart muscle was hypertrophied with patchy areas of fibrosis. The lungs were œdematous. No other organs were abnormal. The atheromatous plaque occluding the left coronary artery, which was considered the direct cause of death, was dissected off the aorta and analysed for its lipid content. A section of the wall from an area of healthy ascending aorta was similarly treated. The findings are compared in Table I with the composition of serum taken one week before death. Desmosterol constituted 20 per cent of the sterols in the atheromatous plaque, compared to 43 per cent in the serum.

TABLE I

Composition of Lipids AND STERols (PERCENTAGE BY Weight)

\begin{tabular}{|c|c|c|c|c|c|c|c|c|c|}
\hline & & & & \multicolumn{2}{|c|}{ Atheroma } & \multicolumn{2}{|c|}{ Aorta } & \multicolumn{2}{|c|}{ Serum } \\
\hline & & & & Lipids & Sterols & Lipids & Sterols & Lipids & Sterols \\
\hline $\begin{array}{l}\text { Cholesterol.. } \\
\text { Desmosterol } \\
\text { Phospholipid } \\
\text { Triglyceride }\end{array}$ & $\begin{array}{l}\cdots \\
\cdots \\
\cdots\end{array}$ & $\begin{array}{l}\cdots \\
\cdots \\
\cdots\end{array}$ & $\begin{array}{l}\cdots \\
\cdots \\
\ldots\end{array}$ & $\begin{array}{c}51 \\
12 \\
37 \\
\text { none }\end{array}$ & $\begin{array}{l}80 \\
20 \\
- \\
-\end{array}$ & $\begin{array}{l}40 \\
12 \\
34 \\
14\end{array}$ & $\begin{array}{l}78 \\
22 \\
- \\
-\end{array}$ & $\begin{array}{r}30 \\
23 \\
41 \\
6\end{array}$ & $\begin{array}{l}57 \\
43 \\
- \\
-\end{array}$ \\
\hline
\end{tabular}


Case 2. A man, 43 years of age, has idiopathic hypercholesterolæmia with hypertriglyceridæmia. A cutaneous xanthoma first appeared on one arm three years ago. Others followed, and led to his examination and diagnosis in January 1961. The serum cholesterol then was over $900 \mathrm{mg} . / 100 \mathrm{ml}$. He was started on MER-29, $250 \mathrm{mg}$. daily, in February 1961, and he was continued on this for 13 months until it was suspended in March 1962. Xanthomata continued to appear and grow during treatment. In March 1962 a biopsy was made of a cutaneous xanthoma from the left upper arm, which had appeared for the first time in May 1961, three months after starting MER-29. The lipid composition of this lesion is shown in Table II and compared

TABLE II

COMPOSITION OF LIPIDS AND STEROLS (PERCENTAGE BY WEIGHT)

\begin{tabular}{|c|c|c|c|c|c|c|c|c|}
\hline & & & & & \multicolumn{2}{|c|}{ Xanthoma } & \multicolumn{2}{|c|}{ Serum } \\
\hline & & & & & Lipids & Sterols & Lipids & Sterols \\
\hline $\begin{array}{l}\text { Cholesterol } \\
\text { Desmosterol } \\
\text { Phospholipid } \\
\text { Triglyceride }\end{array}$ & $\begin{array}{l}\cdots \\
\cdots \\
\cdots\end{array}$ & $\begin{array}{l}\cdots \\
\cdots \\
\cdots \\
\cdots\end{array}$ & $\begin{array}{l}\cdots \\
\cdots \\
\ldots \\
\ldots\end{array}$ & $\begin{array}{l}\cdots \\
\cdots \\
\cdots \\
\cdots\end{array}$ & $\begin{array}{l}26 \\
34 \\
23 \\
17\end{array}$ & $\begin{array}{l}43 \\
57 \\
- \\
-\end{array}$ & $\begin{array}{l}21 \\
10 \\
25 \\
44\end{array}$ & $\begin{array}{l}68 \\
32 \\
- \\
-\end{array}$ \\
\hline
\end{tabular}

with the serum composition at the time of the biopsy. While the serum sterols contained 32 per cent desmosterol, those in the xanthoma contained 57 per cent, a higher proportion than was found in the serum at any time during the growth of the xanthoma.

\section{Discussion}

Avigan and Steinberg (1962) have recently reported that desmosterol was deposited in the experimental atheromatous lesions of a rabbit in the same proportion as was present in the serum. Our results strongly suggest that the same is true for sterol deposition in hypercholesterolæmia in man. The atheromatous plaque analysed in Case 1 must have enlarged to a significant extent during the 15-month period of MER-29 treatment, since evidence of coronary artery obstruction first appeared after the start of treatment and this progressively increased. The proportion of desmosterol in the whole plaque suggests that the recently deposited fraction contained at least as high a proportion as was present in the serum. The xanthoma in Case 2 was entirely deposited during MER-29 therapy and contained a higher proportion of desmosterol than was ever found in the serum. Blankenhorn, Maronde, and Scholtz (1961) and Chobanian and Hollander (1961) found no desmosterol in the atheromatous lesions of three patients dying after four to nine months of MER-29 treatment: in these patients, however, there was no direct evidence that the actual lesions studied had developed or grown during MER-29 treatment. Without such evidence, the absence of desmosterol from those lesions does not mean that it will be absent from actively growing lesions.

It seems then, in both hypercholesterolæmic man and in the experimental animal, that desmosterol behaves no differently from cholesterol in regard to atheroma and xanthoma formation. While MER-29 does cause an initial fall in the total sterol level of serum, as well as in the cholesterol level, this effect was not sustained in our patients. After an average of 13 months' treatment in 18 patients, the total sterol level was only 1 per cent lower on average than at the start of treatment. These findings suggest that the site of action of MER-29 in the biosynthetic pathway for cholesterol is too late to be useful in the prevention of atheroma.

\section{SUMMARY}

In two patients with gross hypercholesterolæmia triparanol (MER-29) treatment failed to inhibit the rapid deposition of sterols in the aorta and the skin. Analysis of lesions laid down, partly or wholly during MER-29 treatment, suggested that desmosterol participated equally with cholesterol 
in the formation of atheromatous and xanthomatous lesions. No evidence has been obtained to suggest that triparamol in any way influences the course of rapidly developing atheroma or xanthomatosis.

\section{REFERENCES}

Avigan, J., and Steinberg, D. (1962). Lancet, 1, 572.

Blankenhorn, D. H., Maronde, R. F., and Scholtz, J. R. (1961). Circulation, 24, 889.

Chobanian, A. V., and Hollander, W. (1961). Circulation, 24, 1086.

Jose, A. D., Learoyd, B., and Peak, H. (1961). Med. J. Aust., 2, 938.

Steinberg, D., Avigan, J., and Feigelson, E. B. (1961). J. clin. Invest., 40, 884. 